\title{
The Evolution of the Iowa Precinct Caucuses
}

\author{
Hugh Winebrenner
}

IowA's emergence as a weather vane in presidential politics is a recent development. Prior to 1972, the Iowa caucuses were just another electoral event in the middle of the national caucus and primary schedule. When the Iowa Democratic party decided to schedule their caucuses in January rather than March or April, they began a chain of events which resulted in the caucuses becoming a national phenomenon.

The lowa caucuses have evolved from the early scandalplagued days of the nineteenth century to their present position of national prominence. In those early days, small groups of individuals attempted to control the local parties by limiting participation in the caucuses. Throughout the early twentieth century various state legislatures enacted measures which brought the previously unregulated caucuses under the rule of law. In the last decade the Iowa Republican and Democratic parties made a number of changes in the conduct of the caucuses which eventually brought them national media attention far in excess of what might be expected for state parties electing so few delegates to their respective national conventions.

Theoretically, the caucus and convention system begins

The author would like to thank Richard Schulze of the State Law Library for his research assistance on the Code of lowa. 
with precinct caucuses open to all party voters. The local caucuses elect delegates to county conventions which, in turn, elect delegates to district and state conventions where the delegates to the national party conventions are selected. The system is a product of Jacksonian democracy of the early 1830 s which, by 1840 , had replaced the congressional and legislative caucuses as the method of nominating public officials in the United States. Since it "was neither recognized nor regulated by law," party bosses gained control of the system during the latter half of the nineteenth century. ${ }^{1}$

lowa joined the Union in 1846 and the state's political parties immediately adopted the national practice of a caucus and convention system. As in other states, charges of manipulation soon emerged. Emory H. English, in an excellent article on voting practices in Iowa, outlines a number of common caucus abuses. Generally, cliques or special-interest groups dominated within party organizations and did their best to limit participation by opposing factions or the general public. The times and locations of caucuses often were closely guarded secrets, and "snap" caucuses were a favorite device of those "in the know." The knowledgeable would assemble on short notice, elect'a slate of delegates to the county convention, and quickly adjourn. When outsiders knew caucus times, a caucus might be packed with supporters of a particular candidate or slate of delegates, or a "competing event" might be organized. English recounts an example of a "competing event" held in northern Iowa in which "the 'fortunate' burning of an old shed in the outskirts of a small town at exactly the advertised hour ... of the caucus attracted nine-tenths of the people of the village, including members of the volunteer fire department. In the meantime, those in the 'know' assembled at the caucus . . . , selected a 'slate' of delegates without opposition and adjourned."2

Frequent abuses of the caucus process led to calls for reform, but the Iowa General Assembly acted slowly: The first

1. Frank E. Horack, "Primary Elections in lowa," in Applied History, Iowa Applied History Series, vol. 1 (Iowa City, 1912), 266.

2. Emory H. English, "Evolution in Iowa Voting Practices," Annals of Iowa 29 (April 1948), 257. 
reform bill was not introduced until 1896. Reformers focused on developing a system of primary elections in Iowa rather than taking the less radical step of revising the caucus and convention system. Three reform bills were introduced and rejected by the 26th General Assembly in 1896, but in 1898 the 27th General Assembly enacted a "voluntary" primary election law for counties. The first "compulsory" primary election law passed the 30th General Assembly in 1904, but it applied to counties with populations in excess of 75,000 people and Polk was the only county affected. ${ }^{3}$

In 1907, eleven years of reform efforts in the General Assembly culminated with the passage of a statewide primary election law. The law provided for primary elections to nominate candidates for any office filled by direct popular vote in the general election with the exception of judges. It also required that delegates to the party county conventions, members of the county central committees, and presidential and vicepresidential electors be nominated by primary election. Finally, it required a preference poll for United States senators who at that time were chosen by the state legislature. Since the 1907 law only affected offices filled by direct popular vote, it did not provide for the nomination of presidential candidates. Moreover, the district and state conventions, not popular vote, still selected candidates to the national presidential conventions. The 1907 law, however, did represent a major change in Iowa electoral politics since it opened the previously closed party system to the voters and limited party control over the nominating process. ${ }^{4}$

Although amended several times, the 1907 law remained substantially intact until 1963. There were, however, changes in 1913 and 1917 worthy of examination. In those years Iowa initiated, and then abolished, a presidential primary election.

In 1913 the 35th General Assembly amended Iowa's

3. James J. Crossley, "The Regulation of Primary Elections by Law," Iowa Journal of History and Politics 1 (April 1903), 174-5; Iowa, Acts and Resolutions, 27th General Assembly, 1898, Chap. 111, 59; Iowa Acts and Resolutions, 30th General Assembly, 1904, Chap. 40, 29.

4. Iowa, Acts and Resolutions, 32nd General Assembly, 1907, Chap. 51, 51. 
primary election law to include the selection of delegates and alternate delegates to national conventions of all political parties, the selection of national committee members for each party, and a presidential preference poll "for the purpose of ascertaining the sentiment of voters of the state in the respective parties as to candidates for president and vice-president of the United States."5

Iowa held its only presidential primary election on April 10, 1916, with mixed results. None of the major presidential candidates entered the primary and less than one-third of the eligible electorate voted. The primary election process cost the state $\$ 122,000$. Governor George W. Clarke, who, in his inaugural address of January 16, 1913, had called for the passage of a presidential preference primary law, now branded the 1916 presidential preference poll a farce. In his final biennial message to the General Assembly in 1917, he urged the repeal of the entire direct primary law and called for the return to the caucus and convention system of selecting candidates for public office. ${ }^{6}$

The 37th General Assembly was not willing to abolish the direct primary law in its entirety, but did agree with Governor Clarke's assessment of the presidential preference primary election. A bill to repeal this section unanimously passed both houses in early 1917 and the newly inaugurated governor, William G. Harding, signed it into law on February 16, 1917.'

The next major modification of the caucus and convention system occurred in 1963 when the General Assembly amended Iowa's primary election law and returned the selection of county convention delegates to the precinct caucuses. Two years later, lawmakers also removed the selection of party county commit-

5. Iowa, Acts and Joint Resolutions, 35th General Assembly, 1913, Chap. 111, 99.

6. Steven E. Schier, The Rules of the Game: Democratic National Convention Delegate Selection in lowa and Wisconsin (Washington, D.C., 1980), 58, In 49; Des Moines Register, 30 January 1917, 2; Iowa, Inaugural Address of Governor George W. Clarke to the Thirty-Fifth General Assembly, 16 January 1913, 19-20; lowa, Biennial Message of Governor George W. Clarke to the Thirty-Seventh General Assembly, 9 January 1917, 27.

7. Iowa, Acts and Joint Resolutions, 37th General Assembly, 1917, Chap. 14, 32 . 
tee members from electoral politics and provided for their selection at precinct caucuses. Several factors contributed to these changes including the high cost of printing separate ballots for each precinct, the low visibility of party offices, and a movement in Iowa for a shorter ballot. ${ }^{8}$ No additional substantive changes to the lowa primary law occurred after 1965 . The current law requires primary elections to nominate candidates for all elective officials below the office of president with the exception of judges, and provides for a caucus and convention system for selecting delegates to the presidential conventions.

When the General Assembly returned Iowa to the caucus and convention system for selecting delegates and committee members, it placed the caucuses on sound statutory footing. Iowa law provides that "delegates to county conventions of political parties and party committee members shall be elected at precinct caucuses not later than the second Monday in February on each even-numbered year." 9

The actual date for precinct caucuses is set by the state central committee of each party, and since 1976 the Republican and Democratic parties have held their caucuses on the same day. The principal motivation for this unusual example of party cooperation in lowa is to gain maximum media exposure, and in that regard they have succeeded. ${ }^{10}$ The state central committee determines a uniform starting time for all Democratic caucuses. The county central committees control the starting time for Republican caucuses in each county, which results in some variation in the evening starting times. Iowa law also requires that "the date, time, and place of each precinct caucus of a political party shall be published at least twice . . . not more

8. Iowa, Acts and Joint Resolutions, 60th General Assembly, 1963, Chap. 78, 117; Iowa, Acts and Joint Resolutions, 61st General Assembly, 1965, Chap. 89, 158; interview with Clifton Larson, former chairman, Iowa Democratic Party, 23 February 1981.

9. Iowa Code, Sec. 43.4.

10. Interview with Tim Hyde, 8 October 1982. Hyde, former executive director of the Republican Party of Iowa, provided two additional reasons for the Republicans' willingness to initiate a common caucus date: to maximize caucus participation through joint announcements and to prevent people from participating in both the Republican and Democratic caucuses. 
than thirty days and not less than five days before the date of the caucuses." In addition the notice must state in substance that each voter affiliated with the specified political party may attend the precinct caucus. Finally, whenever possible, precinct caucuses are to be held in publicly owned buildings or in places used for holding public meetings. ${ }^{11}$

The requirements are intended to ensure an open and well publicized caucus process and have succeeded in eliminating most of the earlier abuses. It is still possible, however, to pack a caucus with supporters of a particular candidate or slate of delegates, but greater media coverage and the correspondingly higher salience of the caucuses make the use of this tactic increasingly difficult, especially in presidential election years.

The legislation of 1965 also determined rules of eligibility for caucus participation. The law requires that caucus participants reside within the precinct and that they are or will be eligible electors by the next general election. The law permits seventeen-year-olds who will be eighteen by the time of the general election to participate in the caucuses. Since the precinct caucuses are party-sponsored events, the parties can have, and each has, additional requirements for participation. Neither party requires that participants be registered to vote, but the Iowa Republican party requires that participants "declare" themselves Republicans and authorizes the resolution of eligibility disputes at caucuses by majority vote. The Democratic party limits participation to those who are "supporters of the purpose of the Democratic party and are not members of any other political party." Although the goal of these requirements is to prevent raiding, it is very unlikely that persons willing to "declare" themselves supporters of the party on the evening of the caucus will be prevented from participating by either party. ${ }^{12}$

Voting procedures within caucuses are at the discretion of each caucus gathering, although the Republican State Central

11. Iowa, Code, Sec, 43.92 , Sec. 43.93.

12. Ibid., Sec. 43.90; Republican Party of Iowa, "Suggested Procedure for Precinct Caucuses, January 21, 1980," mimeographed (Des Moines, 1980); lowa Democratic Party, "Precinct Caucus Kit, 1980," mimeographed (Des Moines, 1980). 
Committee suggests votes be taken by secret ballot. Moreover, any questions not covered in state law or by party rules are resolved by majority vote of the caucus voters.

The principal concerns of the precinct caucuses are delegate selection and the development of issues for the party platforms, but the parties vary somewhat in their conduct of business. Both normally elect two precinct committee members to represent their precinct on the county central committees. Each begins the platform-building process by developing and discussing issues which are then forwarded to the county platform committees. Republican caucuses "take stands" and Democrats "prioritize" the issues. The Democratic caucuses elect members and alternates to serve on the Platform Committee and the Committee on Committees planning the county conventions. The Republican County Committees determine the procedures for filling these positions and they vary by county. The foremost concern of the party caucuses is the election of delegates to their respective county conventions, and in presidential years, Democratic and Republican procedures differ significantly.

The Democrats practice a system of proportional representation: Delegates to the county conventions are elected in proportion to the levels of support for presidential candidates in each caucus. There may be, and usually is, an uncommitted group. A candidate preference or uncommitted group is viable - eligible to elect delegates to the county convention - only if it includes a minimum of 15 percent of the total caucus voters. If more than 85 percent of those voting at a caucus support one presidential candidate, or are uncommitted, they are entitled to elect the entire slate of delegates to the county convention. ${ }^{13}$

Delegate selection at Democratic caucuses is a multi-step process with opportunities for bargaining and politicking at each stage. After the chair determines the number of eligible

13. The 15 percent rule applies to caucuses electing four or more delegates. The minimum figures for viability in caucuses electing fewer delegates are: three delegates $-16^{2 / 3}$ percent, two delegates -25 percent, and one delegate -50 percent plus one. 
voting members in attendance, caucus participants divide into presidential preference groups. When that stage is completed, groups are counted for purposes of determining viability, and preference groups that fail to meet minimum viability standards have the opportunity to reassociate with other groups. At this point, politicking increases in intensity as viable groups seek to proselytize the "groupless" voters in order to increase the number of delegates for which they qualify. When all voters are members of a viable candidate preference or uncommitted group, the caucus chair again counts the groups and determines the number of delegates to the county convention which each is entitled to elect. The chair informs county headquarters of the number of delegates committed to each candidate, as well as the number selected as uncommitted, and the final step of delegate selection begins. Delegate selection within groups is usually a lively and spirited process which frequently involves speechmaking, bargaining, and vote trading.

Party officials claim that the system of proportional representation makes it possible to project the number of delegates that each Democratic presidential candidate will have among those ultimately comprising the Iowa delegation to the national convention. In 1972, Iowa Democratic officials responded to national media requests for "results" of the caucus process by preparing a list of sample precincts for purposes of projecting statewide caucus candidate support. In 1976, under State Chairman Tom Whitney, the Democrats established a "caucus returns headquarters" at the Des Moines Hilton with a phone reporting system by party chairs from Iowa's ninety-nine counties. A party staffer was present and provided immediate analysis of support patterns from around the state. The enterprising Whitney charged all present ten dollars for the service. ${ }^{14}$

The projections resulting from these Democratic efforts are highly tentative since some delegates are selected as "uncommitted," none is legally bound at succeeding steps in the process, and possibly, indeed probably, one or more of the presidential hopefuls will drop out of the race prior to the county conventions leading to realignments of delegates previously supporting

14. Schier, Rules of the Game, 145, 316. 
those candidacies. The 1976 and 1980 caucuses provide interesting contrasts as to the accuracy of national convention delegate strength projections based on caucus outcomes. The 1976 projection indicated that Jimmy Carter would control 13 of Iowa's 47 national convention delegates, Morris Udall 3, others 13 , and "uncommitted" 18 . On the first ballot, Iowa's delegates gave Carter 25 votes, Udall 20, Jerry Brown 1, and Ted Kennedy 1 , which certainly calls the accuracy of the caucus projections into question. In 1980, with an incumbent president and fewer candidates for the nomination, the projections of future delegate strength proved to be very accurate. Democratic officials projected that the lowa delegation would include 31 Carter supporters, 16 Kennedy, and 5 uncommitted delegates. The totals of those ultimately selected, and bound by the 1980 national convention rules, were Carter 31, Kennedy 19, and 2 uncommitted. ${ }^{15}$

The Republican delegate selection process in presidential caucus years is less complex than the Democrats' system. The Republicans generally select their delegates on an "at large" basis, although individual caucuses determine their selection procedures, and should they desire, elect delegates on a proportional basis. A precinct electing six delegates at large would allow each caucus participant to vote for as many as six delegates, and the persons receiving the most votes are elected regardless of their presidential preference. A well organized candidate organization possibly could pack a caucus and with a simple majority control all the delegates elected, a feat requiring 85 percent at Democratic caucuses. The Republican delegate selection process probably leads to the selection of more party regulars to the county convention than the proportional system used by the Democrats.

The Republican at-large system does not lend itself to projecting the composition of the delegation to the national convention. In response to media pressure for concrete outcomes from the caucus process and the desire to maximize the attention given to the Iowa caucuses, the Iowa Republicans initiated

15. Interview with Marie Menne, former caucus chairperson, Iowa Democratic Party, 23 February 1981. 
a presidential preference poll in 1976. Beginning modestly, sixty-two scientifically selected precincts conducted the poll; by 1980, all caucuses did so.

The poll occurs prior to the delegate selection process, but there is no requirement that delegates elected later in the evening reflect the sentiments expressed by the poll. Delegates are not committed or bound to any candidate. Consequently, the poll has little scientific basis for predicting candidate support among the Iowa delegation to the Republican National Convention. Republican officials, however, note that in 1976 the poll predicted very accurately the breakdown within the delegation to the national convention. In that year, the poll results indicated that 45.3 percent of those attending Republican caucuses supported President Gerald Ford, 42.5 percent favored Ronald Reagan, and 10.6 percent were undecided. The Iowa delegation split 19 for Ford and 17 for Reagan on the first ballot at the convention. In 1980 the poll was a complete failure as a predictor. George Bush was favored by 32 percent of the caucus participants, Ronald Reagan by 30 percent, and several other candidates divided the remaining votes. The Bush advantage increased at the county conventions, but by the national convention, Reagan supporters were in complete control of the Iowa delegation and cast a unanimous vote for Reagan.

$F_{\text {rom a }}$ a position of relative obscurity, the Iowa precinct caucuses moved toward national prominence in 1972 when the Iowa Democratic Party moved its caucus date forward to January 24 , making it the first primary event in the nation. The early date for the caucuses is the result of an interesting series of events. The Iowa General Assembly first passed legislation governing the date of precinct caucuses in 1969. The law required that caucuses be held "not later than [the] second Monday in May in each election year," but did not limit how early they might be held. Prior to 1972, the Iowa parties tended to hold their precinct caucuses in late March or in April, which fell in the middle of the national primary schedule. The Democratic National Committee prompted the move by deciding to hold its national convention on July 9, 1972, which was somewhat earlier than usual. The Iowa Democratic Party constitution in- 
cluded a clause requiring thirty days between party functions (precinct caucuses, county conventions, congressional district conventions, the state statutory convention, the state presidential convention, and the national convention), and due to the early date for the national convention, the latest possible date for the caucuses in 1972 was January 24. The January date moved the lowa Democratic Party caucuses ahead of the New Hampshire primary election which was traditionally the nation's first primary event. ${ }^{16}$

The thirty-days-between-events clause in the party constitution arose from practical rather than philosophical considerations. According to Cliff Larson, Democratic state chair from 1970 to 1973 , the party wanted to include as many Democrats as possible in the caucus process and to provide delegates to the next set of party functions with good sources of information. Unfortunately, the state party headquarters had severe physical limitations and very poor office equipment, so to complete the paper work and arrangements required for each level of meetings, a month interlude between party functions was necessary. Larson maintains there was no political intent in moving the caucus date forward, and confesses that he was unaware the Iowa Democratic caucuses would be the nation's first as a result of the move. He hastens to add, however, that it did not take lowa Democrats long to realize what they had done, and although surprised by the magnitude of the media attention, the Iowa Democratic Party set out to capitalize on its new position of prominence. ${ }^{17}$

The early date for the Iowa precinct caucuses changed their character completely. Prior to 1972, they attracted no national attention. Generally, caucus attendance was poor, and often a handful of party regulars were the only persons present. Thus, even though the meetings were open and the lowa press and other media publicized them extensively, party regulars dominated the precinct caucuses and the candidate selection

16. Iowa, Acts and Joint Resolutions, 63rd General Assembly, 1969, Chap. 90, 124; James Flansburg, "Iowa Caucus Date is First," Des Moines Register, 21 November 1971, Sec. B, 1.

17. Interview with Clifton Larson. 
process. Although empirical evidence is not available, probably many party regulars were happy with limited public participation.

Being the first primary event brought the Iowa Democratic caucuses to the attention of Democratic presidential candidates as well as to the media. When the major Democratic hopefuls campaigned extensively in the state in 1972, increased attention given the caucuses by the candidates and media stimulated voter participation: Turnout for the Democratic caucuses increased from 38,000 in 1968 to 60,000 people in $1972 . .^{18}$

The caucuses received an immediate boost in media attention when the McGovern campaign decided to make a major effort in the state. Muskie also campaigned in Iowa in 1972. The prominence of being first, and frequent visits by the major Democratic candidates, focused a great deal of media attention on the precinct caucuses.

The national attention in 1972 prompted the parties to take steps to further expand interest in, and publicity for, the lowa caucuses. The Republicans, who missed out on the headlines in 1972 by holding their caucuses in April, were anxious to share the limelight with the Democrats. Both parties realized the necessity of a common caucus date to maximize media coverage. The two parties successfully negotiated an agreement to hold the Republican and Democratic caucuses in 1976 on January 19, and have continued the practice of a common date since that time. The Republicans also initiated a presidential poll in $1976 .{ }^{19}$

The common date for the Republican and Democratic caucuses in 1976 set the stage for a real media event and lowa's party leaders were not disappointed. Jimmy Carter targeted Iowa as a testing ground for his campaign and Ronald Reagan challenged President Gerald Ford in the state. The candidates and media representatives visited the state in large numbers and Iowa's caucuses gloried in national attention. Surprisingly, par-

18. Levels of participation are very rough estimates by state party officials and should be treated carefully.

19. Interview with Steve Roberts, former chairman, Republican Party of Iowa, 25 March 1981. 
ticipation in the caucuses was low in 1976. Party officials estimate that 4 percent $(22,000$ to 26,000$)$ of the registered Republicans and 7 percent $(38,500)$ of the eligible Democrats attended. The success of the Carter campaign, and the credit given the Iowa caucuses for his good start virtually guaranteed greater media attention for the 1980 lowa caucuses.

Yet, not everyone was pleased with the consequences of the early caucuses. In late 1977, the Democratic National Committee, concerned about the length and cost of a primary and caucus process that was over five months in duration, began examining alternatives to the drawn out process. When Iowa legislators learned that compression of the primary schedule was a possibility, they reacted to the perceived threat to their now famous caucuses by enacting legislation on March 31, 1978, which required precinct caucuses to be held no later than the second Monday in February in even-numbered years. The Democratic National Committee ultimately included in its procedures for the 1980 National Convention a rule (number 10) requiring caucuses or primaries to be held between the second Tuesday in March and the second Tuesday in June, but included an appeal process for states who had held caucuses or primaries earlier in $1976 .{ }^{20}$

In 1979, Iowa Democrats requested a variance to Rule 10, and after demonstrating that they attempted without success to persuade the Iowa General Assembly to change the caucus law and permit a date which fell within the March to June Democratic National Committee guidelines, received permission to conduct their precinct caucuses in January again. ${ }^{21}$

The candidates and media arrived in Iowa in late 1979 in preparation for the 1980 precinct caucuses. The early date of the Iowa/ caucuses had the effect of moving the entire national caucus and primary process forward, thus lengthening the campaign and increasing the costs to candidates. Although cam-

20. Iowa, Acts and Joint Resolutions, 67th General Assembly, 1978, Chap. 1042, 207; Democratic National Committee, "Delegate Selection Rules for the 1980 Democratic National Convention," mimeographed (Washington, D.C., June 9, 1978), 10.

21. Interview with Marie Menne. 
paign expenses, and particularly media costs, are relatively low in lowa, success in a caucus state is largely dependent on good grass-roots organizing. The successful 1980 campaigns of Jimmy Carter and George Bush again demonstrated this in Iowa. Both spent months putting together their organizations. John Connally, on the other hand, had little or no organization in Iowa and invested heavily in television time with few positive results. ${ }^{22}$

Media coverage of the precinct caucuses was immense. On Iowa caucus night in 1980, all three network national news programs originated from Des Moines. Democratic party leaders estimate media expenditures of over $\$ 3.5$ million to cover the Iowa caucuses, with over two hundred national press people on hand. ${ }^{23}$

The early and sustained attention given the caucuses stimulated interest and officials reported record voter participation throughout the state. The Republican poll indicated that 106,000 persons participated, and the Democrats estimated that 100,000 people attended their meetings. The large turnout included many political amateurs attending their first caucus and some of the usually well-orchestrated events degenerated into rather chaotic affairs. Organizational efforts faltered as meetings spilled over into second and third rooms and supplies ranging from registration forms to ballots were in short supply. The results of large-scale citizen participation in the caucuses produced mixed results. Many meetings elected persons attending their first caucus as delegates to county conventions, and others were at best examples of symbolic democracy as citizens unfamiliar with caucus procedure had little impact. An interesting example of the latter occurred in Republican Caucus 74 in Des Moines, where 474 people attended and participated in the straw poll, but upon completion of the poll approximately half of those present left before the real business of delegate selection took place. ${ }^{24}$

After the 1980 caucuses and primaries, the Democratic par-

22. Ibid.

23. Ibid.

24. Interview with Scott Bittick, caucus member, 23 January 1980. 
ty's National Rules Committee made another move to compress the caucus and primary schedule at a meeting on July 9, 1980. The committee defeated by an 80 to 55 margin an effort to force all precinct caucuses and primary elections into a fourteen-week period between the first Tuesday in March and the second Tuesday in June. They did approve, however, a resolution asking the party's national executive committee to study the length of the presidential selection process. ${ }^{25}$

The Democratic National Committee responded to that recommendation by appointing the Commission on Presidential Nominations (called the Hunt Commission after its chair, North Carolina Governor James Hunt) to consider a number of changes in the nominating process. Their report, dated January 15,1982 , included a recommendation that the length of the Democratic primary season be compressed into a thirteen-week period between the second Tuesday in March and the second Tuesday in June. In deference to Iowa and New Hampshire, they granted permanent exemptions from the time limits for the lowa caucuses and the New Hampshire primary election, although both must be held later than in 1980: Iowa may hold its Democratic caucuses no earlier than fifteen days before the start of the thirteen-week period and New Hampshire seven days. The exception will give Iowa and New Hampshire the opportunity to focus national attention on their primary events as in the past, but may lessen the long-term impact, as candidates will have the opportunity to tumble more quickly from victories (or rebound more quickly from defeats) in Iowa and New Hampshire. ${ }^{26}$ Due to the widespread national attention, the Iowa caucuses have an impact on presidential races far beyond their real significance. Iowa is a small, homogeneous midwestern farming state of small towns and rural areas. In 1980 , only 123 of Iowa's municipalities had populations in excess of 2,500 people, 17 cities exceeded 25,000 persons, and Des Moines, the largest city in the state, had fewer than 200,000

25. Larry Fruhling, "Move to Push Back Iowa's January Caucuses is Killed," Des Moines Register, 10 July 1980, 1.

26. The Democratic National Committee accepted the Hunt Commission's recommendations on March 26, 1982. 
residents. The state's 1980 population of $2,913,808$ was 97 percent white. It sent fifty delegates to the Democratic National Convention and thirty-seven to the Republican Convention in 1980 which was 1.5 percent and 1.9 percent of the total at the respective conventions. Participation in the caucuses is typically less than 10 percent of the electorate, although it grew to about 20 percent in 1980 which was comparable to the turnout for the New Hampshire primary election. Iowa has eight electoral votes. Party competition in Iowa is high, but in presidential elections the state supported the Republican candidate in seven of the last nine races, the exceptions being 1948 and 1964.

Although no state legitimately can claim to mirror the national electorate, Iowa is less representative than many. Larger states legitimately complain that Iowa influences the candidate selection process far more than it should given its lack of demographic and political representativeness. There is a certain irony in the lowa caucuses twice playing a major role in the nomination of Jimmy Carter and then supporting Gerald Ford and Ronald Reagan in the 1976 and 1980 presidential races.

Perhaps more important in placing the lowa caucuses in perspective is the fact that the "results" have little meaning. As previously noted, the caucuses are the first in a multi-step process and the delegates selected at those meetings are not bound to support a particular candidate at the county conventions, nor are delegates from the county to the state conventions bound. (A Hunt Commission recommendation also accepted by the Democratic National Committee at its March 26, 1982, meeting will abolish the 1980 Democratic party practice of binding state delegates at the national convention.) As the field of presidential candidates narrows and as the political process is played out at the county, district, and state conventions, there is always fluctuation in candidate support. Projecting levels of delegate strength - referred to as "national delegate equivalents" by state party officials and the national media - after the first step in a fluid multi-step process is untenable. The "national delegate equivalents" are little more than guesses.

Even so, as long as the Iowa precinct caucuses are the earliest event in the primary season, they undoubtedly will attract a great deal of national attention. It matters little that the 
"results" of the Iowa caucuses are meaningless as predictors of delegate preference within the Iowa delegations to the national conventions. They are significant because they are first and the national media choose to assign importance to them. Media interpretation of caucus "outcomes" in Iowa is crucial to the campaigns of presidential aspirants. The broad coverage of the media advances the campaigns of the "winners" by featuring them on the evening news, the front pages of newspapers, and on the covers of national magazines. They also make it difficult for the less fortunate candidates, branding them "also rans" or "losers." The winners experience renewed vigor in their campaigns and increased success in fund-raising efforts, while the losers' campaigns are set back and they find it more difficult to raise money. In 1976 for example, R. W. Apple of the New York Times in a post-caucus story headline declared that "Carter is Regarded as Getting Big Gains From Iowa Results," an interpretation that "was prevalent on major networks and in major newspapers." 27 The CBS Morning News of January 20, 1976, declared Carter the victor and conducted a rather lengthy interview with him in which they permitted Carter to interpret the impact of the caucuses on his and the other candidates' campaigns. The only other candidate shown during the program was Fred Harris, and he was represented as having finished a poor third. The Washington Star declared Udall's campaign "damaged" on the basis of his fifth-place finish in lowa with only 5.8 percent of the caucus vote. ${ }^{28}$ Yet, at the Democratic National Convention in 1976 Carter, the media winner, received 25 votes and Udall, the loser, 20 votes on the first ballot.

In 1980, the Iowa caucuses provided a tremendous boost to the candidacy of George Bush who shaded the front-runner and heavily favored Ronald Reagan in the Republican poll by a margin of 32 to 30 percent. The media trumpeted his "victory" around the nation. Reagan underestimated the importance of Iowa and chose not to devote his personal energy to campaigning in the state. Bush's star rose dramatically after the victory in

27. R. W. Apple, New York Times, 20 January 1976, quoted in Schier, Rules of the Game, 336.

28. Schier, Rules of the Game, 336. 
Iowa, and he rode the momentum all the way to the Republican vice-presidential nomination.

The national media and officials of both state parties cooperated in selling the caucuses as a weathervane in the presidential selection process. The actions taken by the Democrats in 1972 and 1976 and by Republicans in 1976 and 1980 madé possible a media event by providing "results" or "outcomes" of the caucuses, even though the "results" are of little scientific value and actually may be very' misleading.

The 1984 caucuses will again be the first event in the national primary season and will be conducted under the microscope of the media. Presidential candidates will be in lowa very early, and large sums of money will be expended by the candidates and the media. The national attention tends to increase participation in the caucus process, and state officials of both parties are pleased to be able to identify potential sources of party support nine or ten months prior to the November elections. Because of the media attention, the lowa local meetings which were designed to generate platform issues and select delegates to the county conventions will make or break presidential candidacies and must be taken seriously by all presidential candidates. 
Copyright of Annals of Iowa is the property of State of Iowa, by \& through the State Historical Society of Iowa and its content may not be copied or emailed to multiple sites or posted to a listserv without the copyright holder's express written permission. However, users may print, download, or email articles for individual use. 